\title{
IMPACTS OF TRAINING ON PERCEPTIONS OF ACCESSIBILITY IN TOURISM
}

\author{
Marklea da Cunha Fersta; \\ Helen Rita Menezes Coutinhob
}

ABSTRACT: The search for quality in the provision of tourist services is a constant feature among players in the sector. This study aims to analyze the impact of training on the perception of accessibility among participants in a course on how to serve tourists with disabilities. It uses applied, exploratory and descriptive research, with bibliographic analysis and case studies. Two questionnaires were applied to the same group of participants; one before a training course and the other after. The results of the two questionnaires were then compared, using a mixed approach method. The results showed that the training was able to alter the participants' perceptions of accessibility and improve their skills and competencies in serving tourists with disabilities or reduced mobility. As an academic contribution, this research demonstrates the importance of training in the provision of tourist services for people with disabilities or reduced mobility. As a practical contribution, the article provides a resource for market analysts, human resources professionals, government, businessmen and researchers in the area of tourism, for the development of effective training actions to cater for tourists with disabilities or reduced mobility.

\section{KEYWORDS}

Training;

Accessibility

Perception

Accessible tourism 


\section{INTRODUCTION}

Considered one of the main industries in the world, tourism represents one of the fastest growing sectors on a global scale, second only to manufacturing (World Travel \& Tourism Council, 2019).

It is known that providing quality services to tourists can promote customer loyalty (Yoo \& Bai, 2007), which is an important aspect for any company.

Considering the potential of accessible tourism, which has been identified in the literature as a profitable tourism segment (Rabontu, 2018), and the importance of quality in the provision of tourist services, a training course was offered by the authors to help tourism operators assist people with disabilities or reduced mobility. The participants were asked to fill out questionnaires, at the beginning and end of the course, to find out their perceptions about accessibility. The responses before and after the training were then compared.

In view of the importance of providing quality services for people with disabilities or reduced mobility, and of training of agents who work in customer service, the overall aim of this work is: to analyze the impact of training on perceptions of accessibility. Its specific aims are: (i) to characterize disability and accessibility; (ii) to analyze the importance of providing quality services to assist tourists with disabilities or reduced mobility; and (iii) to demonstrate the importance of attitudinal accessibility in assisting tourists with disabilities or reduced mobility.

\section{ACCESSIBILITY}

According to the current concept of disability, it is necessary to adapt the environment to the needs of people with disabilities, i.e., it is essential to promote an accessible environment that meets the needs of people with disabilities or reduced mobility - PwDMr so that they can fully enjoy their fundamental rights, including tourism and leisure (Degener \& Quinn, 2018; Rabontu, 2018).

To ensure that PCDMr have full enjoyment of their rights, on equal terms with other people, Law $13,146 / 2015$ establishes the obligation to eliminate all barriers that prevent or limit a person's social participation, as well as their enjoyment and fruition and exercise of their right to accessibility (BRASIL, 2015; Leite, Ribeiro, \& Costa Filho, 2016).

Accessibility is characterized as the possibility and condition of accessing spaces, furniture, urban equipment, buildings, transportation, information and communication, as well as services and facilities for public or private use, of collective use, so that the person with disabilities or reduced mobility can use them autonomously and safely (BRASIL, 2015).

In this work, we analyze, specifically, the attitudinal barriers defined by Law 13,146/2015 as "attitudes or behaviors that prevent or impair the social participation of the person with disabilities in equal conditions and opportunities with other people", since these attitudes are directly linked to hospitality and the welcome given to visitors.

\section{Perception, Qualtty and Train-}

\section{IND}

One of the basic principles of human behavior is that people act according to their perceptions and not according to reality. Hastorf $(1973$, p. 18) states that "we perceive people as unitary entities with certain physical and personality characteristics, as well as thoughts and feelings".

Peoples' attributes vary greatly. Physical and personality characteristics are relatively permanent characteristics of a person; thoughts and feelings are more variable. To Hastorf (1973, p. 18) "Physical characteristics and intense emotional states are clear and observable characteristics of people". The thoughts of others can be presented or inferred. Perhaps one of the most salient aspects of a person is his emotional expression.

Perception is the process by which individuals organize and interpret their sensory impressions to give meaning to the environment. However, what a person perceives can be substantially different from the objective reality. It is not necessarily the same for everyone, and often there is a lot of disagreement (ROBBINS, 2000).

But explaining the fact that people can perceive the same thing differently is a very complex task. A number of factors act to shape and sometimes distort perception. These factors may lie with the observer - in relation to the object or target of the perception, or in the context of the situation in which the perception occurs.

The purpose of this investigation is to analyze the perceptions of participants of a training course on accessibility and how much these perceptions can be changed as a result of the training course and the acquisition of new knowledge on the subject.

The tourism sector provides the highest number of jobs worldwide and is composed mainly of small and micro companies, as well as large multinational corporations (Davidson, McPhail, \& Barry, 2011). The services that form part of tourism include hotels, restaurants, theme parks, managed food services, event planning, travel agency, and many others.

As a service industry, customer loyalty and repeat purchases depend partly on the service provided; there- 
fore it is important that employees build good relationships with the customers in order to develop a satisfactory relationship, through a knowledge of the customers' characteristics and habits (Chi \& Gursoy, 2009). However, ensuring service quality can be difficult, due to four characteristics inherent to all service: intangibility and heterogeneity (or variability) due to the fact that customers are co-producers; perishability of production (without stock); and simultaneity of production and consumption.

Customer-employee interaction has a great influence on quality perception and customer satisfaction (Brown, Mowen, Todd Donavan, \& Licata, 2002; Farrell \& Oczkowski, 2012). Thus, human resources practices are essential for good customer service (Irfan, Mohsin, \& Yousaf, 2009). Training is a tool for the development of skills to facilitate interaction with customers and improve the performance of tasks to achieve superior service. (Arroyo-López, Cárcamo-Solís, ÁlvarezCastañón, \& Guzmán-López, 2016).

That said, service is a set of activities performed by a company for the purpose of meeting customers' needs and expectations. Having understood what service is, we can define quality as two factors: technical quality 'profits' and human quality 'beyond profits'. Technical quality aims to satisfy specific requirements and expectations such as: time, quality, finances, rate of defects, function, durability, safety, and guarantee. Human quality, in turn, aims to satisfy expectations and emotional desires such as loyalty, commitment, consistency, behavior, credibility, attitudes and attention. It is important to note that the concepts of 'technical quality' and 'human quality' are complementary (MOLLER, 1992).

Quality is the ability to satisfy needs both at the time of purchase and during use, at the best possible cost, minimizing losses and being better than the competitors.

When dealing with quality in services, SERVQUAL is an important evaluation tool that recommends five dimensions of quality: reliability, responsiveness, empathy, safety and tangible aspects.(FITZSIMMONS, J.; FITZSIMMONS, 2010).

In tourism, due to the characteristic of the intangibility and interactivity of services, tourists evaluate the service quality based mainly on the first three dimensions, which are perceived exclusively through the behavior, attitudes and skills of the employees (Hennig-Thurau, Gwinner, Walsh, \& Gremler, 2004).

In order to improve the quality of service, investment in formal or informal training for frontline employees provides competitive advantage for service companies (Davidson et al., 2011). This training may be in-person or online, the latter having the advantage that it can reach more participants and a wider geographical area, more economically and efficiently than formal and face -to-face training (Brouwers, Makarski, Durocher, \& Lev- inson, 2011) .

The training provided by the authors took place in distance modality. This was for two reasons; firstly, the global Corona virus pandemic of 2020 meant that face-to-face interactions were prohibited, and secondly, in order to reach and provide the training to a greater number of people, at a time to suit the participant.

\section{MethOdOLOGY}

Methodology is the application of procedures and techniques that must be observed for the construction of knowledge in order to prove its validity and usefulness in the different areas of society. Therefore, the importance is understood, of applying methodology in scientific research for a better understanding and greater authenticity in the analyzes, in order to achieve the objectives. (Prodanov \& Freitas, 2013).

In terms of purpose, research can be classified into two groups: Research of an intellectual order, also called 'fundamental' and 'pure' research, which is aimed at gaining knowledge, is carried out by scientists, and contributes to the progress of Science; and research of an applied order, which is aimed at practical applications, with the objective of meeting the demands of modern life. Applied research seeks to resolve a problem by presenting answers to specific questions, through scientific knowledge, in order to provide an immediate managerial decision-making (Cooper \& Schindler, 2016).

This, the purpose of this research is applied, as it aims to contribute to practical purposes, seeking solutions to concrete problems, i.e., promoting the training of agents to serve people with disabilities or reduced mobility.

The scope of this study can be considered exploratory and descriptive, as exploratory studies are carried out when the aim is to examine a theme that has been little studied (Hernández Sampieri, Collado, \& Lucio, 2015). In this case, we sought to analyze the importance of services provision to cater for tourists. The scope of this study then becomes descriptive, as it examines specific properties, characteristics and important details of disability and accessibility. Triviños (1987) reports that descriptive research is marked by the interpretation of the results that appears as the totality of a speculation that is based on the perception of a phenomenon in a context. Thus, it is not empty, but coherent, logical and consistent. The procedures used were bibliographic and field research. Bibliographic research aims to collect and analyze data from material already published on the research topic, in order to explain the contributions on the subject. This differs from documentary re- 
search in which materials that have not yet received an analytical treatment are analyzed. (Fachin, 2017). In this research, a survey was conducted on accessibility, perception and training.

For the field research, the online program SurveyMonkey was used to carry out the empirical investigation with the participants of the training course on serving people with disabilities. This training was conducted by the authors from June 8 to June 22, 2020 in the Virtual Learning Environment (VLE) moodle.

The nature of the research is mixed, as it involves elements of both the qualitative and quantitative approaches (Creswell, 2010). The quantitative method involves the use of the qualification of variables and statistical techniques to ensure the accuracy of the results. But this method is not ideal for explaining complex social phenomena. (RICHARDSON, 1999). Qualitative research, meanwhile, investigates the functioning and structure of social systems (Creswell, 2010).

A mixed approach was used in this work; the participant's perceptions of accessibility by the participants before and after training involved quantitative analysis, while the analysis of open questions required qualitative analysis. This mixed approach allowed for a more robust interpretation and analysis of the results.

In the analysis of qualitative data, data coding was performed using the method recommended in the literature (Creswell \& Clark, 2013); the text was divided into smaller units, such as a word or paragraph, and a label was assigned to each unit for subsequent grouping of the codes into themes.

To achieve the objectives proposed in this investigation, the use of a non-probabilistic sample was defined, but using the techniques of reliability, validity and objectivities necessary for scientific research (Cooper \& Schindler, 2016). In the application of the chosen research instrument - a questionnaire - the intentional non-probabilistic sampling method was used. In the first stage of the data collection, forms with closed and open questions were used. In the second stage, the same form was applied after the participants had completed the course, allowing them to express their thoughts and describe the knowledge they had gained. For the analysis of this work, comparative responses to the two questionnaires were used. However, for the respondents' profile, only data from the second questionnaire was used.

\section{OUtCOMES}

The training course on serving people with disabilities was given by the authors from June 8 to June 16, 2020 in the Virtual Learning Environment (VLE) moodle. In order to access the activities and the educational material, the participant was asked to first answer a questionnaire with questions about his/her profession- al profile and knowledge and perceptions about accessibility; and after completing all phases of the course, to respond to a final questionnaire on accessibility.

Sixty participants answered the initial questionnaire (Q1) and 44 participants answered the final questionnaire (Q2). For profile purposes, only the data from Q2 was analyzed, in which $65.91 \%$ of the participants did not work in any tourist service activity, as shown in table 1. Of the respondents in Q2, 90.91\% (40) had no disability or mobility difficulties; $6.82 \%$ (03) were people with reduced mobility and $2.27 \%$ (01) had some type of disability. Regarding fluency in another language, $61.36 \%$ (27) said they were not fluent in another language; $27.27 \%$ (12) were fluent in English; 9.09\% in Spanish and 2.27\% (01) in Libras (Brazilian Sign Language).

\section{Table 01: Profile of respondents Q2}

\begin{tabular}{l|r|r}
\hline Answer Choices & \multicolumn{2}{|c}{ Responses } \\
\hline $\begin{array}{l}\text { Yes, in a managerial position (Director, Ma- } \\
\text { nager, Administrator, etc.) }\end{array}$ & $4.55 \%$ & 2 \\
\hline $\begin{array}{l}\text { Yes, in s technical position providing direct } \\
\text { service to the public }\end{array}$ & $11.36 \%$ & 5 \\
\hline $\begin{array}{l}\text { Yes, in a technical position, but not provid- } \\
\text { ing direct service to the public }\end{array}$ & $0.00 \%$ & 0 \\
\hline $\begin{array}{l}\text { Yes, as an intern providing direct service to } \\
\text { the public }\end{array}$ & $13.64 \%$ & 6 \\
\hline $\begin{array}{l}\text { Yes, as an intern, but without providing } \\
\text { direct service to the public }\end{array}$ & $4.55 \%$ & 2 \\
\hline $\begin{array}{l}\text { Do not work in any activity that involves } \\
\text { services to tourists }\end{array}$ & $65.91 \%$ & 29 \\
\hline
\end{tabular}

Source: Research data - Q2 (2020)

The participants were asked to state, before starting the course and after its conclusion, whether in general terms, they considered themselves able to provide quality services to a disabled tourist (TwD) (physical, visual, hearing, intellectual or mental) or a tourist with mobility reduced (TwMr) (senior, pregnant, obese, etc.). The results of the research show that after the training, there was a substantial percentage increase in participants' aptitude to provide services to TwD or TwMr. Whereas before the training, only 3.33\% said that "yes, definitely" they considered themselves capable of serving TwD or TwMr, after the training, this percentage increased to $36.36 \%$, as shown in Graph 1.

The result found proves the importance of training in the development of skills and consequent improvement in the performance of tasks and quality of the service provided, confirming the indication of the literature in this regard. (Arroyo-López et al., 2016).

It is important to note that the theme quality in care of people with disabilities has been highlighted in the polices and services for this public; highlighting Maes 
Graph 01 - Aptitude to serve TwD or TwMr

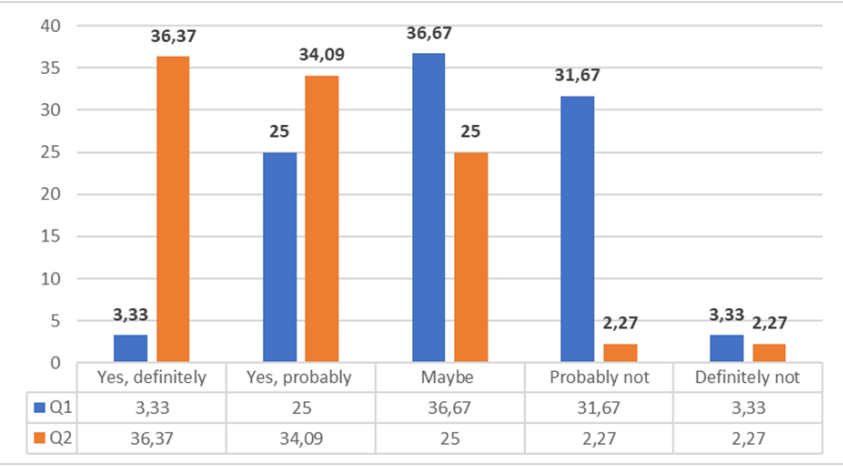

Source: Research data (Q1 and Q2)

( 2003,p.224 ) the existence of significant trends with regard to "quality management, quality standards and quality assessment procedures".

In both questionnaires (Q1 - applied before the course and Q2 - applied afterwards), the participants were asked to state their home town or city and to answer questions about accessibility in that place.

In the first question about the perception of accessibility in their place of residence, the respondents were asked to state, on a five-point Likert scale ("strongly agree" to "strongly disagree"), their degree of agreement or disagreement with the statement: " The city where I live fully meets the needs for accessibility: physical (adequacy of physical spaces - mobility); Communicational (existence of adequate communication); Attitudinal (form of assistance to people with disabilities or reduced mobility); Informational (existence of information on the accessibility of spaces) and Technological (existence of assistive technology)".

The research showed little statistical variation in the responses after the training, with slightly lower responses for physical access, communication, and technological and attitudinal aspects of accessibility. Graph 2 shows the weighted means and standard deviation of each response in Q1 and Q2.

\section{Graph 02 - Perception of accessibility in the} participant's city of residence

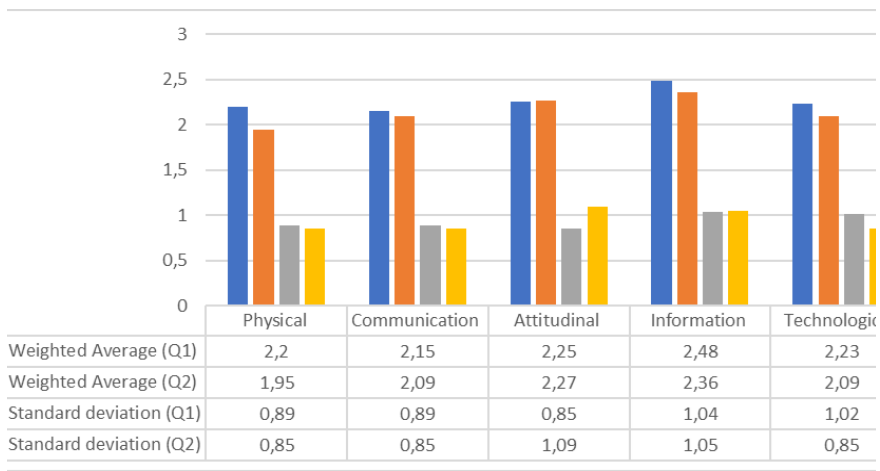

Source: Research data (Q1 and Q2)
In the second question about the perception of accessibility, the respondents were ask to state, on a five-point Likert scale ("strongly agree" to "strongly disagree"), their degree of agreement or disagreement with the statement: "State your level of agreement or disagreement with each of the statements below: "The tourist attractions in the city where I live fully meet the needs of accessibility: physical (adequacy of physical spaces mobility); Communicational (existence of adequate communication); Attitudinal (form of assistance for people with disabilities or reduced mobility); Informational (existence of information on the accessibility of spaces) and Technological (existence of assistive technology)".

After completing the course, the respondents had a slightly stricter perception of the accessibility of tourist attractions of their city, especially physical accessibility; Before the course, the weighted average was 2.33 with a standard deviation of 0.87 , and after the course, this figure was 2.11 with a standard deviation of 0.80 . Graph 3 shows the weighted averages and standard deviations for each response to Q1 and Q2.

\section{Graph 03 - Perception of accessibility to tourist attractions in the participant's city of residence}

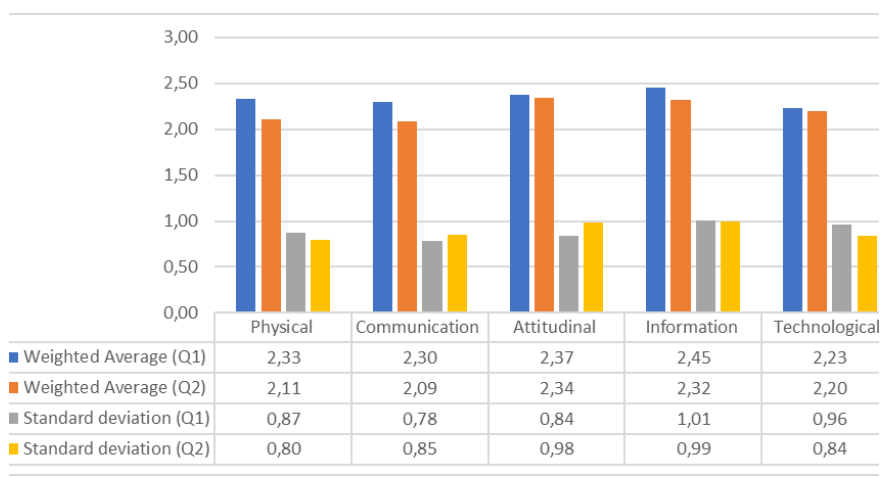

Source: Research data (Q1 and Q2)

It is noted that the perception of accessibility of respondents about the city in which they reside or about their tourist attractions is in line with what has been demonstrated in other surveys that point to the absence of accessibility in cities and tourist attractions in Brazil (Blichfeldt \& Nicolaisen, 2011; Duarte \& Lemos, 2017). And although researchers demonstrate that it is an important tourist segment, States and the tourism industry itself continue to neglect accessible tourism. (Dávid \& Kiss, 2011; Lyu, 2017).

There was a substantial change in the participant's opinion after the course in terms of whether they would recommend the city where they lived for people with disabilities or reduced mobility. On a Likert scale of "yes, definitely" to "definitely not", before the course 
only $3.33 \%$ of the respondents said they would definitely recommend their city to a TwD or TwMr, while at the end of the course, this percentage had increased to $11.36 \%$. However, the mean response in Q1 was 3.12 with standard deviation of 0.83 and in Q2, it was 3.11 with standard deviation of 1.11. Graph 4 shows the data for all variables.

\section{Graph 04 - Whether participants would recommend their city of residence to TwD or TwMr}

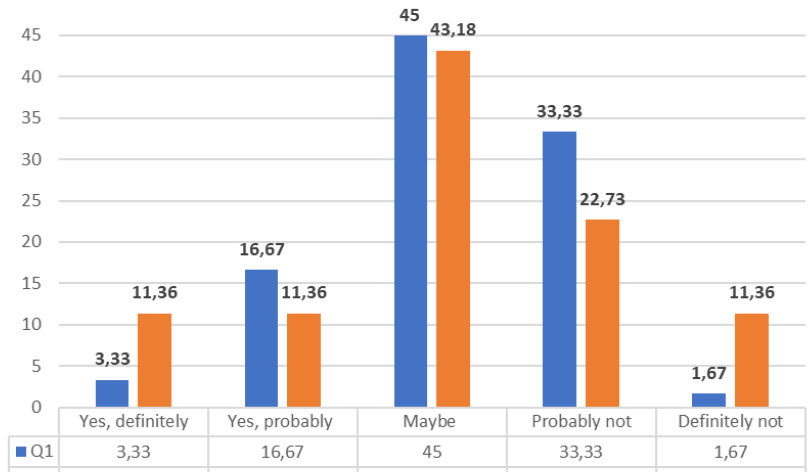

Source: Research data (Q1 and Q2)

Of the participants who replied that they would "yes, definitely" or "yes, probably" recommend their city of residence to a tourist with a disability or reduced mobility, in Q1, 55.56\% said they would, because the city is adapting to accessibility; $11.11 \%$ said they would recommend it but that they would inform the tourist about some of the barriers they would face; and $33.33 \%$ said they would recommend it due to the tourist experience in terms of the culture and natural beauty. Some of the respondents' comments need have yet to be transcribed.

I recommend visiting, although with a warning about the barriers that exist. Respondent no. 12 - ID 191.255.109.107 - resident of São Paulo - Brazil.

The city is being structured to receive tourists with disabilities and people with reduced mobility; there is interest on the part of the government and private initiative in promoting accessible tourism, however, trade still does not have full accessibility, they are seeking to meet the standards but are still in the process of meeting compulsory issues required by law. There is, however, interest and goodwill. Respondent no. 3 - ID 187.25.41.71- resident of the city of Bonito - Brazil

Because my city is beautiful and has many attractions for tourists. Respondent no. 2 - ID 138.204.130.201 resident of Santarém - Brazil.
In Q2, of those who stated that they would "yes, definitely" or "yes, probably" recommend the city where they live to a tourist with a disability or reduced mobility, $44.4 \%$ said they would recommend it because the city is adapting to accessibility; $11.11 \%$ said they would recommend it but that they would inform the tourist of the barriers to be faced; $11,11 \%$ said they would recommend, but they would provide a differentiated service to overcome the barriers; $22.22 \%$ claimed they would recommend it due to the tourist experience in terms of the culture and natural beauty and $11.11 \%$ said they would recommend it depending on the type of disability. Some of the responses to the open questions are transcribed:

Yes, because although accessibility is not fully available in public spaces or private developments, there is an effort to adapt in order to serve tourists with disabilities. I believe it is essential to inform the tourist about the gaps in the destination that prevent it from fully meeting the needs of people with disabilities, leaving it up to the traveler to decide whether to visit the city or not, based on the information provided, as I believe that each tourist, whether disabled or not, has his or her own criteria to consider when choosing a travel destination. Respondent no. 04 - ID 179.214.188.89 resident of Bonito - Brazil

Because it is seeking to adapt to accessibility in general and the population also demands it. Respondent no. 10 - ID 186.243.113.204 - resident of Teresina - Brazil

Yes, although I'd warn them about the various barriers that exist in the city. Respondent no. 09 - ID 191.255.109.107 - resident of São Paulo - Brazil

It is important to highlight that when finding an environment that does not meet his needs and does not offer him a good reception, the tourist hardly returns (Duarte \& Honorato, 2020), and consequently does not recommend either, or if he does, he explains the limitations of the place.

Finally, the participants were asked if they would recommend the training course to other people. $90.91 \%$ (40) said they definitely would, and $9.09 \%$ (04) that they probably would. Interestingly, in the open responses, when asked to explain why they would recommend the course, the participants listed the importance of attitudinal accessibility both for professionals working with tourism and for professionals in other areas. Some of the participants' comments are transcribed below.

The course is excellent and makes a positive contribution to attitudinal change in the services for people with disabilities. Respondent no. 11 - ID 191.189.2.232 - resident of Manaus - Brazil. 
It is an enriching experience and one that can be a tool for educational change in attitudes not only to assist tourists, but also with a valid and practical knowledge of people's daily lives. Respondent no. 28 - ID 191.189.23.201- resident of Manaus - Brazil.

The course is excellent, every professional who works directly or indirectly with tourist services should carry out this type of activity, because this will bring inclusion, as one of the biggest barriers faced by people with disabilities or reduced mobility is attitudinal barriers. I would like to express my thanks to the teachers and for the initiative, because through education, we can transform society into a more humane and inclusive environment. Respondent no. 16 - ID 191.189.22.246 - resident in Manaus - Brazil.

Such considerations prove the importance of promoting training for quality care (Irfan et al., 2009), as well as the importance of attitudinal accessibility in assisting tourists with disabilities or with reduced mobility, since hospitality influences the experience of the tourist (Maes, 2003; Tutuncu, 2017) and, consequently, in his service recommendation.

\section{Final Considerations}

This research provides an important academic and scientific contribution, as the topics examined relate to the quality of service for tourists, especially tourists with disabilities or reduced mobility, and the training of agents who work in this sector.

Through this research, it was possible to demonstrate and analyze the importance of providing services to tourists through concepts and reflections, indicating that in order to better serve the tourist, continuous investments in formal or informal training are necessary for employees who work directly with them.

The data collection instrument consisted of two online questionnaires for the participants of the training course on serving people with disabilities. The questionnaires covered topics designed to outline the respondent's professional profile and their knowledge and perceptions on accessibility. The first questionnaire was answered by a total of 60 respondents, and the second by 44 .

The differences in the results of Q1 and Q2 showed the importance of the training for developing the participants' skills and abilities, since before training, only $3.33 \%$ considered themselves able to serve TwD or TwMr but after the training this percentage was increased to $36.36 \%$, confirming the indications in the literature on the importance of training for quality in the provision of services (Irfan et al., 2009).

In regard to the respondents' perception of whether the city where they lived fully met the accessibility needs, in terms of physical; communicational; attitudinal; informational and technological aspects, the research showed little statistical variation in the responses before and after the training, with lower averages for the physical, communicational, and technological accessibility and higher averages for attitudinal accessibility.

When specifically asked about accessibility in the tourist attractions of the city where they lived, it was noted that after the training, the participants evaluated the physical accessibility of the tourist attractions in a more rigorous way, suggesting a change in their perceptions after the training, in this aspect.

Another important item was whether they would recommend their city of residence for people with disabilities or people with reduced mobility. Before the course, only $3.33 \%$ of the respondents said they would definitely recommend their city for a TwD or TwMr, but after the course this percentage increased to $11.36 \%$. We note that $44.4 \%$ explained that they would recommend their city because it is in the process of adapting to improve its accessibility.

Finally, the participants were asked if they would recommend the training course; $90.91 \%$ (40) said they definitely would and $9.09 \%$ (04) said they probably would, which demonstrates the participants' perception of the importance of training to serve tourists with disabilities or reduced mobility, especially in regard to attitudinal accessibility, as can be seen from the open responses.

The research has some limitations; the main one is the size of the research universe, as not all participants answered both questionnaires. However, it was still possible to evaluate the importance of qualification for service quality. As for future research, it is suggested that a larger number of participants who work directly with providing services to tourists be included.

As an academic contribution, the research demonstrates the importance of training in the provision of tourist services for people with disabilities or reduced mobility, as can be seen from the results corroborated with the literature review that tourists with disabilities demand for more specialized care and tend to build loyalty when your needs are met.

As a practical contribution, this research can be used by market analysts, human resource professionals, government, entrepreneurs and researchers in tourism, to develop effective actions for training in tourist services for people with disabilities or reduced mobility.

\section{REFERENCES}

Arroyo-López, P. E., Cárcamo-Solís, M. de L., Álvarez-Castañón, L., \& Guzmán-López, A. (2016). Impact of training on impro- 
ving service quality in small provincial restaurants. Journal of Foodservice Business Research, 20(1), 1-14. https:// doi.org/10.1080/15378020.2016.1192881

Blichfeldt, B. S., \& Nicolaisen, J. (2011). Disabled travel: not easy, but doable. Current Issues in Tourism, 14(1), 79-102. https://doi.org/10.1080/13683500903370159

Brasil. (2015). Lei 13.146, de 6 de julho de 2015. Retrieved April 3, 2019, from http://www.planalto.gov.br/ccivil_03/ _Ato2015-2018/2015/Lei/L13146.htm

Brouwers, M. C., Makarski, J., Durocher, L. D., \& Levinson, A. J. (2011). E-learning interventions are comparable to user's manual in a randomized trial of training strategies for the AGREE II. Implementation Science, 6(1), 1-10. https:// doi.org/10.1186/1748-5908-6-81

Brown, T. J., Mowen, J. C., Todd Donavan, D., \& Licata, J. W. (2002). The customer orientation of service workers: Personality trait effects on self-and supervisor performance ratings. Journal of Marketing Research, 39(1), 110-119. https://doi.org/10.1509/jmkr.39.1.110.18928

Chi, C. G., \& Gursoy, D. (2009). Employee satisfaction, customer satisfaction, and financial performance: An empirical examination. International Journal of Hospitality Management, 28(2), 245-253. https://doi.org/10.1016/ j.ijhm.2008.08.003

Cooper, D. R., \& Schindler, P. (2016). Métodos de pesquisa em administração (10a ed.). Porto Alegre: AMGH.

Creswell, J. W. (2010). Projeto de pesquisa [recurso eletrônico]: métodos qualitativo, quantitativo e misto. Tradução Magda Lopes (3a. ed.). Porto Alegre: Artmed.

Creswell, J. W., \& Clark, V. L. P. (2013). Pesquisa de métodos mistos [recurso eletrônico]: tradução: Magda França Lopes (2a ed.). Porto Alegre: Penso.

Dávid, L., \& Kiss, N. (2011). Destination development and management for disabled people. Journal of Tourism Challenges \& Trends, 4(2), 113-122.

Davidson, M. C. G., McPhail, R., \& Barry, S. (2011). Hospitality HRM: Past, present and the future. International Journal of Contemporary Hospitality Management, 23(4), 498-516. https://doi.org/10.1108/09596111111130001

Degener, T., \& Quinn, G. (2018). A survey of international, comparative and regional disability law reform. Retrieved March 27, 2019, from https://dredf.org/news/publications/ disability-rights-law-and-policy/a-survey-of-internationalcomparative-and-regional-disability-law-reform/

Duarte, D. C., \& Honorato, T. S. (2020). Turismo cultural acessível: a percepção dos gestores dos principais teatros de Brasília. Turismo - Visão e Ação, 22(3), 575-596. https:// doi.org/10.14210/rtva.v22n3.p575-596

Duarte, D. C., \& Lemos, G. D. S. (2017). Turismo acessível: estudo da legislação brasileira e internacional sobre os direitos de pessoas com deficiência. Inclusão Social, 10(2), 119-131. https://doi.org/10.22478/ufpb.1981$0695.2018 \mathrm{v} 13 \mathrm{n} 2.43015$
Fachin, O. (2017). Fundamentos de metodologia: Noções básicas em pesquisa científica (6a ediçã). São Paulo: Saraiva.

Farrell, M. A., \& Oczkowski, E. (2012). Organisational identification and leader member exchange influences on customer orientation and organisational citizenship behaviours. Journal of Strategic Marketing, 20(4), 365-377. https:// doi.org/10.1080/0965254X.2011.643917

Fitzimmons, J.; Fitzimmons, M. (2010). Administração de serviços: operações, estratégia e tecnologia de informação. Porto Alegre: Bookman.

Hastorf, S. (1973). Percepção de pessoa. São Paulo: Edgard Blucher.

Hennig-Thurau, T., Gwinner, K. P., Walsh, G., \& Gremler, D. D. (2004). Electronic word-of-mouth via consumer-opinion platforms: What motivates consumers to articulate themselves on the Internet? Journal of Interactive Marketing, 18(1), 38-52. https://doi.org/10.1002/dir.10073

Hernández Sampieri, R., Collado, C. F., \& Lucio, M. D. P. B. (2015). Metodologia de pesquisa (5a ed.). Porto Alegre: Penso.

Irfan, S. M., Mohsin, M., \& Yousaf, I. (2009). Achieving service quality through its valuable human resources: An empirical study of banking sector of Pakistan. World Applied Sciences Journal, 7(10), 1222-1230.

Leite, F. P. A., Ribeiro, L. L. G., \& Costa Filho, W. M. da. (2016). Comentários ao Estatuto da Pessoa com Deficiência. (Org., F. P. A. LEITE, L. L. G. RIBEIRO, \& W. M. da COSTA FILHO, Eds.). São Paulo: Comentários ao Estatuto da Pessoa com Deficiência.

Lyu, S. O. (2017). Which accessible travel products are people with disabilities willing to pay more? A choice experiment. Tourism Management, 59, 404-412. https://doi.org/10.1016/ j.tourman.2016.09.002

Maes, B. (2003). Evaluating quality of support from the perspective of persons with intellectual disabilities: A review. Scandinavian Journal of Disability Research, 5(3), 224-243. https:// doi.org/10.1080/15017410309512627

Moller, C. (1992). O lado humano da qualidade: maximizando a qualidade de produtos através de desenvolvimento das pessoas. São Paulo: Pioneira.

Prodanov, C. C., \& Freitas, E. C. de. (2013). Metodologia do trabaIho científico: métodos e técnicas da pesquisa e do trabaIho acadêmico (2a ed.). Novo Hamburgo: Feevale.

Rabontu, C. I. (2018). the Accessibility of Persons With Disabilities in Romanian Tourism. Revista de Turism - Studii Si Cercetari in Turism, 25, 1-6. Retrieved from http:// www.revistadeturism.ro/rdt/article/view/401

Richardson, R. J. et al. (1999). Pesquisa social: métodos e técnicas (3a ed.). São Paulo: Atlas.

Robbins, S. P. (2000). Administração: mudanças e perspectivas. São Paulo: Saraiva.

Triviños, A. N. S. (1987). Introdução à pesquisa em ciências sociais: a pesquisa qualitativa em educação. São Paulo: Atlas. 
Tutuncu, O. (2017). Investigating the accessibility factors affecting hotel satisfaction of people with physical disabilities. International Journal of Hospitality Management, 65, 29-36. https://doi.org/10.1016/j.ijhm.2017.06.002

World Travel \& Tourism Council. (2019). Travel \& Tourism Global economic impact \& trends 2019 